\title{
The Effect of Roselle (Hibiscus sabdariffa L.) Flowers Extract on the Apoptosis of Fibroblast Proliferation in Keloids
}

\author{
Imam Budi Putra ${ }^{1 *}$, Hardyanto Soebono ${ }^{2}$, Sumadio Hadisahputra ${ }^{3}$, Adang Bachtiar $^{4}$ \\ ${ }^{1}$ Department of Dermatology and Venereology, Faculty of Medicine, Universitas Sumatera Utara, Indonesia; ${ }^{2}$ Department \\ of Dermatology and Venereology, Faculty of Medicine, Universitas Gajah Mada, Indonesia; ${ }^{3}$ Department of Pharmacology, \\ Faculty of Pharmacy, Universitas Sumatera Utara, Indonesia; ${ }^{4}$ Department of Health Policy and Administration, Faculty of \\ Public Health, Universitas Indonesia, Indonesia
}

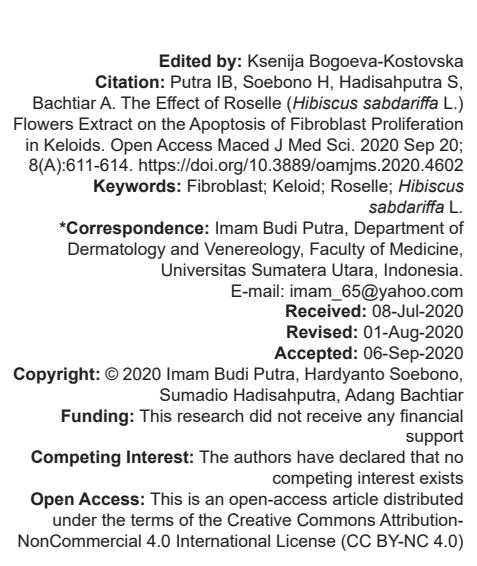

\section{Introduction}

Keloids are defined as raised fibrous scars that overgrow the boundaries of the original wound. Its name originated from Greek word "cheloides" which means crab [1]. Patients can experience pain and itchiness, also cosmetic aspect that greatly affect quality of life of keloid patient [2]. Keloid is thought to be caused by imbalance between increase synthesis of collagen and extracellular matrix with decreased degradation of these components. There is increased activity of fibroblast, which results from upregulation of transforming growth factor- $\beta 1$ (TGF- $\beta 1$ ) and TGF- $\beta 2$ with decreased expression TGF- $\beta 3$. TGF- $\beta 1$ has also known to increase tissue inhibitors of metalloproteinases and decrease matrix metalloproteinases. Vascular endothelial growth factor (VEGF) and plateletderived growth factor (PDGF) are also contributes in increase collagen production [3]. Treatment options of keloids are varied, including pressure therapy, silicone gel, intralesional injection (corticosteroid, 5-FU, methotrexate, and bleomycin), cryotherapy, laser, and surgical excision [1]. However, successful therapy in keloids still remains challenging and no single effective modality has been proven yet. Therefore, more studies and development of new modalities are necessary.

Herbal medicine has been part of our society for centuries. Until now, only few studies have been done to explore the potential of natural resources in the treatment of keloid. Recently, roselle (Hibiscus sabdariffa L.) has become popular due to high anthocyanin content that found in the leaves, flowers, and fruits. This antioxidant is known to have liver protective effect and might play a role in the prevention of cancer and heart disease. According to Chang et al., Hibiscus anthocyanin can induce apoptosis of promyelocytic leukemia cells [4]. 
Furthermore, Huang et al. also reported that anthocyanin can inhibit proliferation and migration of vascular smooth muscle cells, which involves connective tissue growth factor signaling pathway [5]. Therefore, this antioxidant might have potential effect on fibroblast proliferation. The aim of this study is to determine the effect of roselle flower extract on fibroblast proliferation and apoptosis in keloid.

\section{Methods}

This is an in vitro experimental study of roselle (H. sabdariffa L.) flower extract on human keloid fibroblast cultured cell. The flowers of identified and certified roselle plant by Indonesian Science Center were dried at $35^{\circ} \mathrm{C}$ for $5-7$ days and mashed with blender into simplicia. Then, $200 \mathrm{~g}$ of the simplicia was soaked in ethanol $96 \%$ for $3 \mathrm{~h}$, evaporated at $50^{\circ} \mathrm{C}$, and freeze dried for $24 \mathrm{~h}$ to produce the roselle flower condensed extract. Human keloid tissue was excised and washed with sterile phosphate buffer saline (PBS). Then, it was cut into small pieces and put into Petri discs with PBS/Roswell Park Memorial Institute medium and gentamycin 2\%. Dulbecco's Modified Eagle's Medium $10 \%$ was added as culture media and put in $\mathrm{CO}_{2}$ incubator at $37^{\circ} \mathrm{C}$ until the Petri discs full of cells that can be harvested and subcultured into flash.

Tunnel assay was done to detect apoptosis of the cultured fibroblast cells in different concentrations (1.96 $\mu \mathrm{g} / \mathrm{ml}, 3.91 \mu \mathrm{g} / \mathrm{ml}, 7.81 \mu \mathrm{g} / \mathrm{ml}, 15.63 \mu \mathrm{g} / \mathrm{ml}$, $31.25 \mu \mathrm{g} / \mathrm{ml}, 62.50 \mu \mathrm{g} / \mathrm{ml}, 125 \mu \mathrm{g} / \mathrm{ml}, 250 \mu \mathrm{g} / \mathrm{ml}$, $500 \mu \mathrm{g} / \mathrm{ml}$, and $1000 \mu \mathrm{g} / \mathrm{ml}$ ) after incubated at $37^{\circ} \mathrm{C}$ for one night. All the mediums were carefully removed using PBS and the cells were fixated on slides using formaldehyde $4 \%$ in PBS with $\mathrm{pH} 7.4$ at $4^{\circ} \mathrm{C}$ for $25 \mathrm{~min}$ then immersed in PBS for 5 min at room temperature for washing process with two repetitions. The slides then immersed in $0.2 \%$ Triton $\mathrm{X}-100$ for $5 \mathrm{~min}$ and washed with PBS twice. After carefully dried, the slides were buffered and put under plastic cover with wet tissue paper underneath to maintain the humidity. The slides were inserted to humidified chamber and covered with aluminum foil, then incubated at $37^{\circ} \mathrm{C}$ for $60 \mathrm{~min}$ for tailing reaction. The reaction was stopped with immersion of the slide in $2 \times$ SSC solution for $15 \mathrm{~min}$ in room temperature and washed with PBS 3 times for $5 \mathrm{~min}$. Then, staining process was done with propidium iodide $1 \mu \mathrm{g} / \mathrm{mL}$ for $15 \mathrm{~min}$ at room temperature in the dark and then washed with aquadest 3 times for $5 \mathrm{~min}$. The slides were carefully dried and sealed for fluorescence microscopic evaluation.

Enzyme-linked immunosorbent assay (ELISA) was done to evaluate TGF- $\beta 1$ level of the cultured human keloid fibroblast after given roselle flowers extract. Ten series with different concentrations of the extract were added to supernates of the cultured fibroblast in 96 wells and diluted with $50 \mu \mathrm{L}$ RD1-21 followed by incubation for $2 \mathrm{~h}$ at room temperature. Each well was aspirated and buffer washed, then $100 \mu \mathrm{L}$ TGF- $\beta 1$ conjugates were added and incubated for another $2 \mathrm{~h}$ at room temperature. Aspiration and buffer wash repeated before adding $100 \mu \mathrm{L}$ substrate solution in each well followed by $30 \mathrm{~min}$ incubation at room temperature and covered from lights. Diluted hydrochloric acid solution was added to stop the reaction and ELISA reading with $450 \mathrm{~nm}$ wavelength followed to determine the TGF- $\beta 1$ titer.

Cytotoxicity assay was also done to determine viability of the cultured fibroblast cells in each concentration using ELISA. The fibroblast cells from normal human skin were cultured and 10 concentrations of roselle flower extract were added, then incubated for $24 \mathrm{~h}$. Dimethylthiazol diphenyltetrazolium in $5 \mathrm{mg} / \mathrm{mL}$ PBS was added to each well and followed with incubation for 4-6 h. Stopper solution (SDS 10\% in HCL $0.1 \mathrm{M}$ ) was added overnight, and the absorbance results were read with $550 \mathrm{~nm}$ wavelength.

The assays were done in triple repetition and all documented data were statistically analyzed. Linear regression test was done to determine the relation between apoptosis of the cultured fibroblast cells and TGF- $\beta 1$ titer with different concentration of roselle $(H$. sabdariffa L.) flower extract. One-way ANOVA test was done to analyze the differences of absorbance value in each concentration.

\section{Results}

Tunnel assay result revealed that the apoptosis rate of the cultured fibroblast cells from human keloid increased with higher concentration of roselle (H. sabdariffa L.) flower extract (Table 1).

Table 1: Association between the concentration of roselle (Hibiscus sabdariffa L.) flower extract with mean apoptosis rate and TGF- $\beta 1$ titer of the cultured human keloid fibroblast cells

\begin{tabular}{lllll}
\hline $\begin{array}{l}\text { Concentration } \\
(\mu \mathrm{g} / \mathrm{mL})\end{array}$ & $\begin{array}{l}\text { Mean apoptosis } \\
\text { rate }(\%)\end{array}$ & $\begin{array}{l}\text { TGF- } \beta 1 \text { titer } \\
(\mathrm{pg} / \mathrm{mL})\end{array}$ & $\begin{array}{l}\text { Absorbance }(\mathrm{OD}) \\
(\text { Mean } \pm \mathrm{SD})\end{array}$ & $\begin{array}{l}\text { Cell } \\
\text { viability }(\%)\end{array}$ \\
\hline Control & 0 & 1072.54 & $1.019 \pm 0.015$ & 93.1 \\
1.96 & 13.22 & 741.66 & $1.002 \pm 0.0032$ & 91.4 \\
3.91 & 17.68 & 688.98 & $1.045 \pm 0.007$ & 89.4 \\
7.81 & 20.43 & 637.69 & $0.970 \pm 0.011$ & 94.7 \\
15.63 & 21.85 & 638.40 & $1.011 \pm 0.051$ & 90.2 \\
31.25 & 26.17 & 622.94 & $1.022 \pm 0.019$ & 89.0 \\
62.5 & 28.65 & 454.34 & $0.998 \pm 0.018$ & 91.6 \\
125 & 40.68 & 353.88 & $0.984 \pm 0.016$ & 93.2 \\
250 & 43.49 & 375.66 & $0.914 \pm 0.021$ & 99.2 \\
500 & 58.32 & 378.47 & $0.874 \pm 0.013$ & 94.9 \\
1000 & 71.69 & 190.20 & $0.826 \pm 0.026$ & 89.7 \\
\hline TGF- $\beta 1$ : Transforming growth factor- $\beta 1$. & & &
\end{tabular}

Linear regression test (Figure 1) also showed strong association between the increase of concentration of roselle $(H$. sabdariffa $L$.) flower extract and the elevation in apoptosis percentage of the cultured human keloid fibroblast cells $\left(r^{2}=0.797 ; p<0.05\right)$.

ELISA evaluation revealed that TGF- $\beta 1$ titer reduction was resulted by the increase in roselle (H. sabdariffa L.) flower extract concentration (Table 1). 


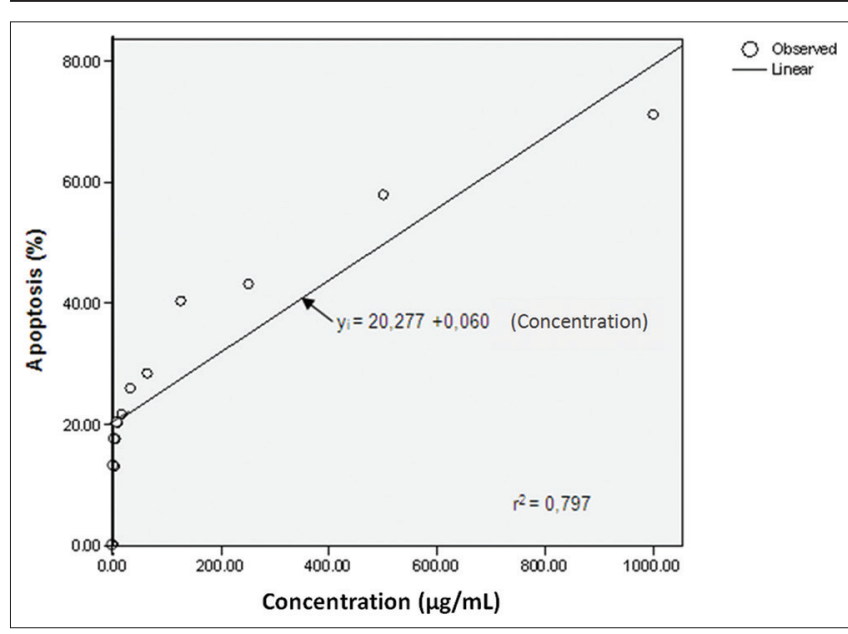

Figure 1: Linear curve of the association of roselle (Hibiscus sabdariffa L.) flower extract concentration with percentage of apoptosis rate

In linear regression test (Figure 2), higher concentration of roselle flower extract is associated with lower TGF$\beta 1$ titer $\left(r^{2}=0.501 ; p<0.05\right)$. In cytotoxicity assay, mean viability of the normal human fibroblast cells was $92.33 \%$. One-way ANOVA analysis showed that there were no differences in absorbance value of each concentrations. As result, roselle ( $H$. sabdariffa L.) flower extract did not show any cytotoxicity effect against human fibroblast cells.

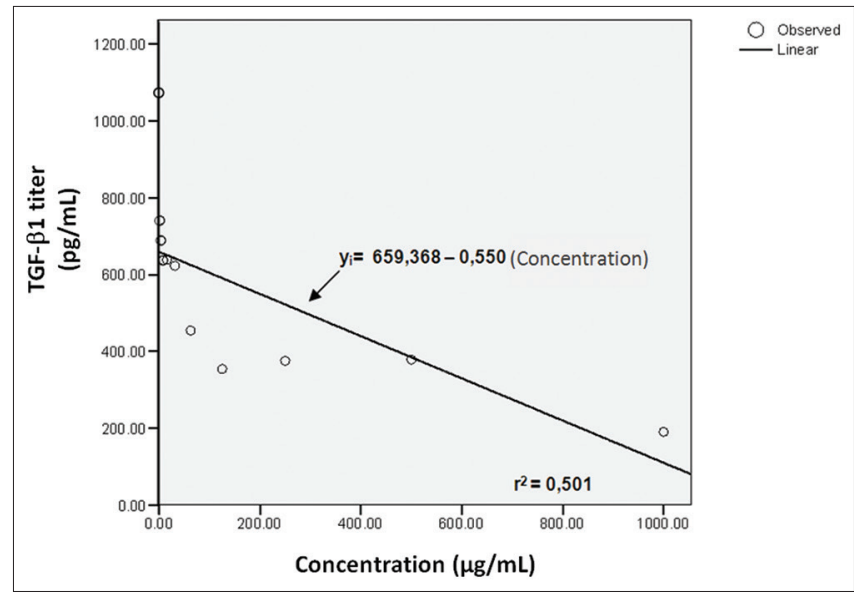

Figure 2: Linear curve of the association of roselle (Hibiscus sabdariffa L.) flower extract concentration with TGF- $\beta 1$ titer

\section{Discussion}

As a fibroproliferative disorder, dysregulation of wound healing pathway plays a crucial role in keloid with initiating activation of keloid fibroblasts and promotes extracellular matrix (ECM). Keloid fibroblasts are thought to be the main inductive cells which initially found highly infiltrating lesion tissue and subsequently mediate elevation of ECM deposition [6], [7]. Therefore, novel therapy targeting these pathogeneses is required to provide treatment option with better efficacy and successful rate. In this study, 10 escalating concentrations of roselle flower extract were tested on the cultured human fibroblast. Apoptosis rate of the keloid fibroblast cells was found to be increased in accordance with the extract concentration. High anthocyanin content in roselle flower extract is thought to play a significant role in inducing fibroblast apoptosis. In vitro studies have shown that anthocyanin-rich extracts exhibited pro-apoptotic effects in multiple cell types through both intrinsic (mitochondrial) and extrinsic (FAS) pathways [8]. In the treatment of cancer, anthocyanin has antitumor effect that inhibited cancer cell growth by targeting on receptor tyrosine kinases, such as epidermal growth factor receptor, PDGF receptor, and VEGF receptor. It also induces cancer cell apoptosis that mediated by ROS and JNK/p38MAPK [9]. In this study, we did not measure the level of anthocyanin content in our roselle flower extract.

In the past decades, TGF- $\beta 1$ pathway is recognized as a pivotal inducer the progress of tissue fibrosis and an important growth factor. There is higher expression of TGF- $\beta 1$ in hypertrophic scar and keloidal tissues that promote proliferation and differentiation of dermal fibroblast, also increased production of collagen [10]. A study showed that TGF- $\beta 1$ production increases according to scar severity [11]. Subsequently, it becomes an important pharmacological target in keloids treatment, with successful antifibrotic strategies based on TGF- $\beta$ signaling inhibition or elimination at various transduction steps. A study by Wang et al. showed promising result of TGF- $\beta$ antagonist peptide in prevention and reduction of hypertrophic scar [12], [13]. In this study, TGF- $\beta 1$ titer was found dose-dependently decrease with roselle $(H$. sabdariffa L.) flower extract. The previous study by Yang et al. also reported that $H$. sabdariffa polyphenol extract (HPE) exhibit reduction of TGF- $\beta 1$ in renal of diabetic rats [14]. With these findings, it is confirmed that extract of $H$. sabdariffa L. flower extract has anti-TGF- $\beta 1$ potential that might be useful keloid prevention and treatment.

Cytotoxicity assay in this study revealed that roselle flower extract has no toxicity effect on normal skin human fibroblast, with $89.7 \%$ viable cells in the extract concentration of $1000 \mu \mathrm{g} / \mathrm{mL}(1 \mathrm{mg} / \mathrm{mL})$. In accordance with this result, Yang et al. also reported that cell viability was not significantly altered by $0.05-1 \mathrm{mg} / \mathrm{mL}$ of HPE. However, when the concentration increased to $5 \mathrm{mg} / \mathrm{mL}$, only $20 \%$ of the cells were viable [14]. Therefore, maximum concentration of $1 \mathrm{mg} / \mathrm{mL}$ is considered safe without any cytotoxicity effect.

This is the first study to acknowledge the effect of $H$. sabdariffa L. flower extract on human keloid fibroblast cells. With the promising effect of inducing fibroblast apoptosis and TGF- $\beta 1$ reduction, the application of roselle flower extract might be able to provide good alternatives in the treatment of keloids. 


\section{Conclusion}

Roselle $(H$. sabdariffa L.) flower extract was found to induce apoptosis of the cultured fibroblast cells and reduction of TGF- $\beta 1$ titer in dose-dependent pattern, without cytotoxicity effect against human fibroblast cells. With these promising effects, it has a great potential in the novel treatment strategies of keloids. Further studies are required to determine the efficacy of roselle flower extract in human keloid lesion either as therapy or prevention.

\section{Data Availability}

All the data used to support the findings of this study are available from the corresponding author on request.

\section{Acknowledgment}

The authors would like to thank Nelva Karmila Jusuf for the supports and encouragement.

\section{References}

1. Dunsky K, Brissett A. Keloids and hypertrophic scars. In: Sataloff RT, editor. Sataloff's Comprehensive Textbook of Otolaryngology: Head and Neck Surgery: Facial Plastic and Reconstructive Surgery. London: JP Medical Ltd.; 2015.

2. Kouwenberg CA, Bijlard E, Timman R, Hovius SE, Busschbach JJ, Mureau MA. Emotional quality of life is severely affected by keloid disease: Pain and itch are the main determinants of burden. Plast Reconstr Surg. 2015;136(4):150-1. https://doi. org/10.1097/01.prs.0000472474.17120.84

3. Betarbet $U$, Blalock TW. Keloid: A review of etiology, prevention, and treatment. J Clin Aesthet Dermatol. 2020;13(2):33-43. PMid:32308783

4. Chang YC, Huang HP, Hsu JD, Yang SF, Wang CJ. Hibiscus anthocyanins rich extract-induced apoptotic cell death in human promyelocytic leukemia cell. Toxicol Appl Pharmacol. 2005;205(3):201-12. https://doi.org/10.1016/j.taap.2004.10.014 PMid:15922006

5. Huang CN, Chan KC, Lin WT, Su SL, Wang CJ, Peng CH. Hibiscus sabdariffa inhibits vascular smooth muscle cell proliferation and migration induced by high glucose-A mechanism involves connective tissue growth factor signals. J Agric Food Chem. 2009;57:3073-79. https://doi.org/10.1021/ jf803911n

PMid: 19301817

6. Shih B, Garside E, McGrouther DA, Bayat A. Molecular dissection of abnormal wound healing processes resulting in keloid disease. Wound Repair Regen. 2010;18(2):139-53. https://doi.org/10.1111/j.1524-475x.2009.00553.x PMid:20002895

7. Gauglitz GG, Korting HC, Pavicic T, Ruzicka T, Jeschke MG. Hypertrophic scarring and keloids: Pathomechanisms and current and emerging treatment strategies. Mol Med. 2011;17:113-25. https://doi.org/10.2119/molmed.2009.00153 PMid:20927486

8. Wang LS, Stoner GD. Anthocyanins and their role in cancer prevention. Cancer Lett. 2008;269(2):281-90. https://doi. org/10.1016/j.canlet.2008.05.020

PMid: 18571839

9. Lin BW, Gong CC, Song HF, Cui YY. Effects of anthocyanins on the prevention and treatment of cancer. $\mathrm{Br} \mathrm{J}$ Pharmacol. 2017;174:1226-43. https://doi.org/10.1111/bph.13627 PMid:27646173

10. Liu Y, Li Y, Li N, Teng W, Wang M, Zhang T, et al. TGF- $\beta 1$ promotes scar fibroblasts proliferation and transdifferentiation via up-regulating MicroRNA-21. Sci Rep. 2016;6(1):32231. https://doi.org/10.1038/srep32231

11. Kim SY, Nam SM, Park ES, Kim YB. Differences in hypertrophic scar fibroblasts according to scar severity: Expression of transforming growth factor $\beta 1$ at the mRNA and protein levels. Arch Aesthetic Plast Surg. 2015;21(3):116-20. https://doi. org/10.14730/aaps.2015.21.3.116

12. Wang X, Gao Z, Wu X, Zhang W, Zhou G, Liu W. Inhibitory effect of TGF- $\beta$ peptide antagonist on the fibrotic phenotype of human hypertrophic scar fibroblasts. Pharm Biol. 2016;54(7):1189-97. https://doi.org/10.3109/13880209.2015.1059862 PMid:26135051

13. Lu L, Saulis AS, Liu WR, Roy NK, Chao JD, Ledbetter S, et al. The temporal effects of anti-TGF- $\beta 1,2$, and 3 monoclonal antibody on wound healing and hypertrophic scar formation. J Am Coll Surg. 2005;201:391-7. https://doi.org/10.1016/j.jamcollsurg.2005.03.032 PMid:16125072.

14. Yang YS, Wang CJ, Huang CN, Chen ML, Chen MJ, Peng CH Polyphenols of Hibiscus sabdariffa improved diabetic nephropathy via attenuating renal epithelial mesenchymal transition. J Agric Food Chem. 2013;61(31):7545-51. https://doi. org/10.1021/jf4020735 